\section{Virale agenser ved nedre luftveisinfeksjoner hos barn}

Nedre luftveisinfeksjoner forårsaker omtrent en femdel av dødsfallene hos barn under fem år på verdensbasis. Det samme spektrum av virus som gir bronkiolitt i Norge, ble funnet i en brasiliansk studie.

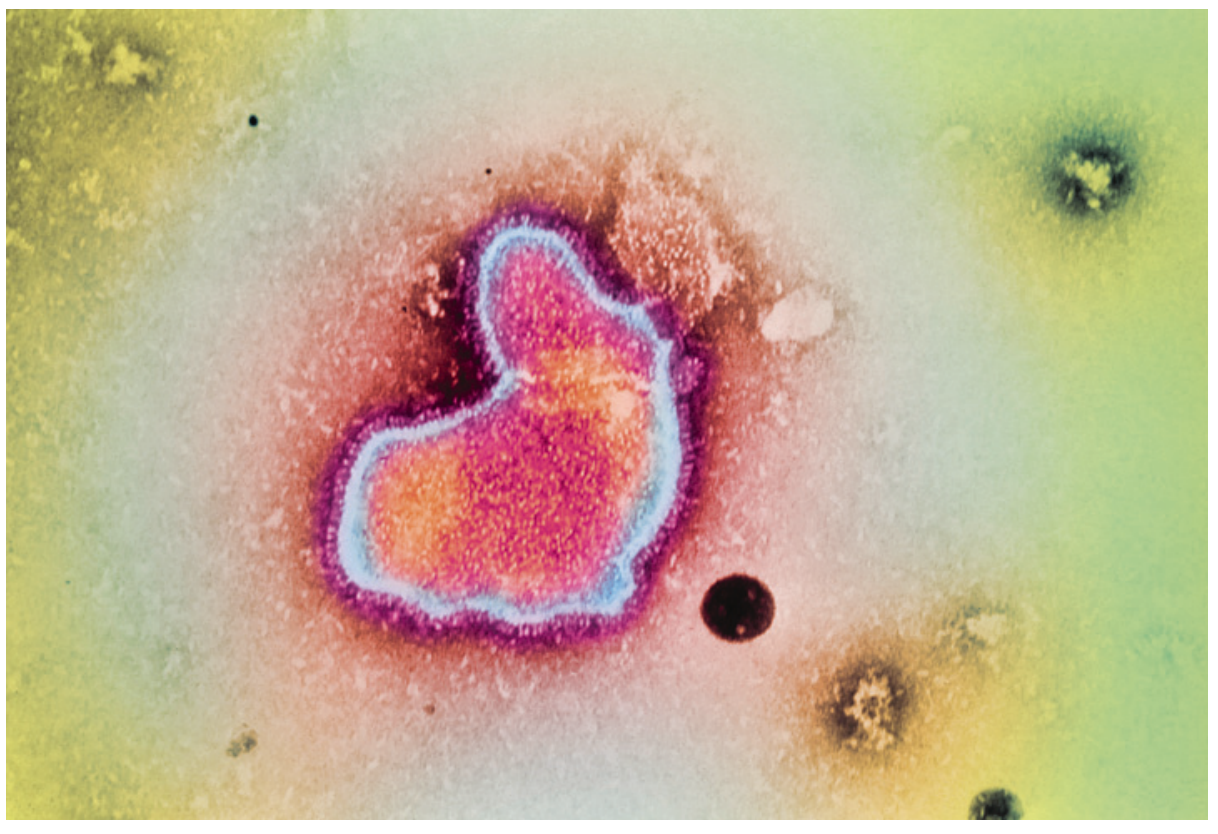

Illustrasjonsfoto Science Photo Library/NTB scanpix

Ved et tertiærsykehus ble barn under tre år med nedre luftveisinfeksjon undersøkt for virale agenser. Etter eksklusjon av dem med bakteriell pneumoni analyserte man med polymerasekjedereaksjon nasopharynxsekret fra 260 barn mot 13 luftveisvirus (1). Nesten halvparten var under seks måneder, og $24 \%$ var født prematurt. Flertallet av sykehusets pasienter kommer fra fattige familier.

Hos 222 av barna ( $85 \%$ ) ble det påvist ett eller flere virus, og det var koinfeksjoner hos 146 barn (56\%). Vanligst var RS-virus (54\%), humant metapneumovirus (32\%) og rhinovirus $(21 \%)$. De to førstnevnte hadde en klart høyere forekomst i den kalde sesongen. Hos barn med koinfeksjon med rhinovirus og RSvirus varte sykehusoppholdet $\mathrm{i}$ justerte analyser 4,5 dager lenger $(p=0,004)$ enn hos $\emptyset$ vrige barn. De samme virusene var assosiert med oksygenbehandling lenger - 1,4 dager mer for rhinovirus og 4,75 dager mer for RS-virus sammenliknet med øvrige virus. Dessuten ble barn over seks måneder behandlet lenger med oksygen enn eldre barn (3,8 dager i ujusterte analyser).

- Dette er et viktig arbeid, idet de funn som er gjort, tyder på at de fleste luftveisinfeksjoner, også i u-land, er forårsaket av forskjellige typer virus, sier overlege Hallvard Reigstad ved Barneklinikken Bergen.

- Tradisjonelt har man vært svært liberal med til dels bredspektrede antibiotika. Denne studien tyder på at støttebehandling med oksygen og eventuelt bronkodilaterende behandling bør vektlegges mye sterkere, tilføyer Reigstad.

\section{Kristoffer Brodwall}

kristoffer.brodwall@gmail.com

Institutt for global helse og samfunnsmedisin Universitetet i Bergen

\section{Litteratur}

1. da Silva ER, Pitrez MC, Arruda E et al. Severe lower respiratory tract infection in infants and toddlers from a non-affluent population: viral etiology and co-detection as risk factors. BMC Infect Dis 2013; 13: 41

\section{Thyreoideahormon- avhengige nerveceller styrer blodtrykket}

\author{
En nyoppdaget gruppe nerveceller \\ i hjernen regulerer blodtrykk og \\ pulsfrekvens hos mus. De kontrol- \\ leres av thyreoideahormoner.
}

Forskere har nylig identifisert en ny gruppe nerveceller i fremre hypothalamus hos mus (1). Cellene ble karakterisert ved nærvær av proteinet parvalbumin. De hadde spesifikke intracellulære reseptorer for thyreoideahormoner. Selektiv fjerning av disse nevronene førte til økning i gjennomsnittlig arterietrykk og pulsfrekvens. Hos mus med en inaktiv hormonreseptor ble det identifisert færre parvalbuminpositive nerveceller. Dette tyder på at thyreoideahormoner påvirker utviklingen av disse kontrollnevronene. Hypotyreose hos mor kunne ha en avgjørende rolle i utviklingen av denne nevrongruppen hos fosteret og være en risikofaktor for hjerte- og karsykdom senere i livet.

- Thyreoideahormoner virker inn på hjertet og det sympatiske nervesystem ved å øke hjertefrekvens, slagvolum og blodtrykk, sier professor Joel Glover ved Institutt for medisinske basalfag, Universitetet i Oslo. - I denne studien oppdaget man at thyreoideahormoneksponering $\mathrm{i}$ fosterlivet hos mus er nødvendig for utviklingen av en spesifikk nervecellepopulasjon i hypothalamus som regulerer kardiovaskulær funksjon. Fordi hypothalamus står for en overordnet styring av både thyreoidea og det sympatiske nervesystemet, viser denne oppdagelsen en tidligere ukjent interaksjon mellom nervøs og endokrin regulering av kardiovaskulær funksjon, sier han.

- Spesielt interessant er det utviklingsmessige aspektet. For lavt thyreoideahormonnivå i fosterlivet gir færre nerveceller i den nyoppdagede populasjonen og dermed irreversibel hypertensjon senere i livet. Fosterets thyreoideahormonnivå bestemmes av dets egen produksjon og av overføring fra moren. Dette kan være både genetiske og epigenetiske effekter. Funnene kan føre til endringer i dagens behandling av kardiovaskulær sykdom og thyreoideaforstyrrelser og viser en potensielt viktig utviklingsmessig patofysiologisk mekanisme for hjerte- og karsykdommer, sier Glover.

\section{Nicola Herzig}

mspr@broadpark.no

Sandnes

Litteratur

1. Mittag J Lyons DJ Sällström J et al. Thyroid hormone is required for hypothalamic neurons regulating cardiovascular functions. J Clin Invest 2013; 123: $509-16$ 